\title{
DIREITOS MAIS HUMANOS
}

A Revista CEFAC nos leva a pensar, que a Fonoaudiologia, mais do que uma área científica, está voltada ao Humano.

Direitos Humanos.

A ONU defende que um dos maiores direitos de um cidadão é o Direito à INFORMAÇÃO.

Em que, nós fonoaudiólogos, melhoramos a qualidade de vida das pessoas?

Acordar ao toque do despertador, ouvir o barulho de um carro na rua, dizer bom-dia para algum familiar, ligar a TV, assistir às notícias do Brasil e do mundo...

Milhares de pessoas fazem isso todos os dias. Mas nem se dão conta de que, sem uma audição intacta, cada um desses atos cotidianos seria impossível. Escutar, reconhecer os sons para depois transformá-los em pensamento, e devolver uma mensagem para outra pessoa é tão corriqueiro que nem paramos para pensar que esta é a Base da Comunicação.

Só falamos os sons de uma língua porque desde a infância somos expostos a diferentes sons, ruídos e fonemas. Aprendemos que a língua é um código, e pode ser representada de diferentes formas: sonora, escrita, simbólica. E só se comunicam pessoas que têm um código comum, que é feito para ser compartilhado. Em um mundo feito para os ouvintes, em que as mensagens são sonoras, quem não ouve, é excluído.

Pessoas com deficiência somam 24, 5 milhões de brasileiros, o que representa 14\% da população. Dentre as deficiências há as físicas, auditivas, visuais e intelectuais. A luta pela inclusão no Brasil já é antiga. Digo isso com conhecimento de causa porque sou irmã de um moço com Síndrome de Down, que faleceu em 03 de dezembro de 2004 (Dia Internacional da Pessoa com Deficiência), com 34 anos de idade. Fui uma criança que conheceu a luta diária de uma família pela inclusão, em tempos muito mais difíceis e preconceituosos.

O mesmo olhar de repreensão jogado sobre o meu irmão Paulo também era jogado sobre mim e meus pais, como se nós tivéssemos culpa pela deficiência dele. Foram anos e anos de luta pela vida e por um olhar mais "adequado" para esta situação.

Nos países desenvolvidos, a inclusão é uma realidade há muitos anos. Sem um olhar "piegas" ou uma visão "paternalista", pessoas com deficiência fazem parte da sociedade como um todo, sem ter que provar que são iguais, apesar das diferenças.

O Brasil ainda caminha lentamente. Houve avanço na acessibilidade arquitetônica das cidades. Atualmente, cadeirantes já conseguem passear por algumas ruas acessíveis sem problema algum. Cinemas, teatros e restaurantes já possuem banheiros adaptados. Pessoas cegas também se vêem respeitadas e com materiais com braile em elevadores, pisos táteis e bibliotecas acessíveis. Pessoas com deficiência intelectual tiveram a garra dos pais que montaram APAEs pelo Brasil todo e contam com assessorias nas escolas públicas para a inclusão destes alunos. Empresas também procuram cumprir as Cotas determinadas pelo governo e aos poucos, pessoas com deficiência deixam suas casas e passam a fazer parte do mundo corporativo.

Contudo, os surdos foram os que menos tiveram ganhos reais nestas conquistas. Livros, vídeos e pessoas que saibam a Libras são escassos em nosso meio. Provavelmente porque a maior dificuldade seja a Comunicação.

Até o momento, os surdos não conseguiram se fazer entender. Mas este fato precisa mudar.

Mudar é preciso porque a sociedade caminha para um olhar humanitário sobre as pessoas. E isto provoca mudanças de comportamento. Se percorrermos a história, veremos que as primeiras conquistas foram das mulheres (que até hoje disputam melhores cargos profissionais), depois os negros, e agora as pessoas com deficiência e os idosos que clamam por uma inserção. 
E as mudanças não podem ser só arquitetônicas ou empresariais, mas devem ser principalmente ATITUDINAIS. O conceito da inclusão e da prática da diversidade não deve estar só nas leis e livros pedagógicos, mas devem estar na prática, dentro de nós.

Que os artigos desta Revista tragam contribuições reais para a sociedade, e que possamos cada vez mais, termos a Comunicação à serviço do ser, MAIS humano!

\section{Cláudia Cotes}

Fonoaudióloga do UOL e da EPTV (afiliada da Rede Globo). Doutora em Linguística. Presidente da Oscip Vez da Voz, que luta pela inclusão da pessoa com deficiência.

Criadora do Telelibras, primeiro telejornal inclusivo da Internet brasileira e da Mídia Inclusiva, um novo modelo de Comunicação que mistura som, imagem, legenda, Libras e audiodescrição. www.vezdavoz.com.br 